\title{
Hanford Underground Storage Tank Waste Filtration Process Evaluation
}

by

B. W. Walker

Westinghouse Savannah River Company

Savannah River Site

Aiken, South Carolina 29808

D. McCabe

\section{MASTER}

A document prepared for TO BE SHARED WITH OTHER DOE SITES at , , from - .

DOE Contract No. DE-AC09-96SR18500

This paper was prepared in connection with work done under the above contract number with the U. S. Department of Energy. By acceptance of this paper, the publisher and/or recipient acknowledges the U.S. Government's right to retain a nonexclusive, royalty-free license in and to any copyright covering this paper, along with the right to reproduce and to authorize others to reproduce all or part of the copyrighted paper. 


\section{DISCLAIMER}

This report was prepared as an account of work sponsored by an agency of the United States Government. Neither the United States Government nor any agency thereof, nor any of their employees, makes any warranty, express or implied, or assumes any legal liability or responsibility for the accuracy, completeness, or usefulness of any information, apparatus, product, or process disclosed, or represents that its use would not infringe privately owned rights. Reference herein to any specific commercial product, process, or service by trade name, trademark, manufacturer, or otherwise does not necessarily constitute or imply its endorsement, recommendation, or favoring by the United States Government or any agency thereof. The views and opinions of authors expressed herein do not necessarily state or reflect those of the United States Government or any agency thereof.

This report has been reproduced directly from the best available copy.

Available to DOE and DOE contractors from the Office of Scientific and Technical Information, P. O. Box 62, Oak Ridge, TN 37831; prices available from (423) 576-8401.

Available to the public from the National Technical Information Service, U. S. Department of Commerce, 5285 Port Royal Road, Springfield, VA 22161. 
WSRC-TR-97-00353

Rev. 0

\section{Distribution}

W.B. Van Pelt, 676-T

W.L. Tamosaitis, 773-A

R.A. Peterson, 773-A

B.A. Reynolds, PNNL

J.G.H. Geeting, PNNL

C.P. McGinnis, ORNL

C.A. Nash, 773-42A 


\section{DISCLAIMER}

Portions of this document may be illegible electronic image products. Images are produced from the best available original document. 
WSRC-TR-97-00353

Revision 0

Keywords: Cross-flow Filtration

Retention: Permanent

\section{Hanford Underground Storage Tank Waste Filtration Process Evaluation (U)}

September 30, 1997

B.W. Walker, 773-42A

D.J. McCabe, 773-43A

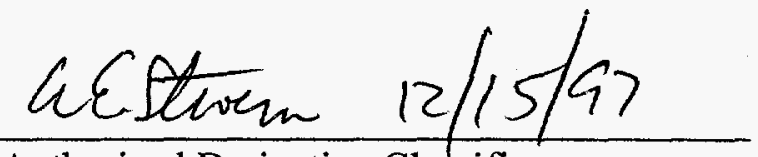

Authorized Derivative Classifier

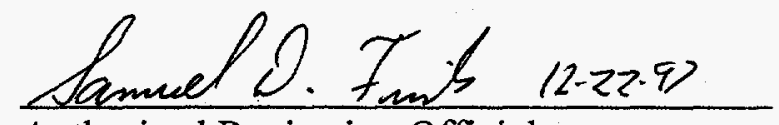

Authorized Reviewing Official

Savannah River Technology Center

Westinghouse Savannah River Company

Aiken, SC 29808

Prepared for the Department of Energy

Office of Science and Technology

Tanks Focus Area Program

Technical Task Plan SR16-WT-41 
WSRC-TR-97-00353

Page 2 of 28

\section{Summary}

Treatment processes have been proposed to use cross-flow filtration to filter supernate and concentrated sludge High Level Waste streams at Hanford. A 0.05 wt \% slurry (simulating supernate waste) and $8 \mathrm{wt} \%$ slurry (simulating sludge waste) were filtered with a 0.5 micron sintered metal Mott filter and 0.1 micron sintered metal Graver filter coated with titania.

- For the concentrated (8.0 wt \%) Hanford simulant, a 0.5 micron Mott filter produced a higher and more consistent filtrate flow rate than the 0.1 micron Graver filter.

- For the dilute $(0.05 \mathrm{wt} \%)$ Hanford simulant, a 0.1 micron Graver filter produced a higher filtrate flow rate than the 0.5 micron Mott filter.

- The $8 \mathrm{wt} \%$ slurry simulating the sludge waste can be concentrated to $14.5 \mathrm{wt} \%$ insoluble solids with the Mott filter.

- Mott filtrate flux does not decrease significantly with filtration time during concentration of $8 \mathrm{wt} \%$ slurry to $14.5 \mathrm{wt} \%$ indicating fouling of the filter is not occurring during this process.

- Cleaning of the filters was performed using $2 \mathrm{wt} \% \mathrm{NaOH}$ and $2 \mathrm{wt} \%$ oxalic acid.

- The filtrate quality for all filter types was comparable, and exceeds the expected criteria for downstream processes.

The filtration processes could be divided according to the mechanism that dominated the filtration process.

- For the dilute Hanford simulants filtrate flow rate is controlled by the transmembrane pressure drop of the slurry across the Mott and Graver filters. The filtrate flow rate was significantly affected by transmembrane pressure drop during filtration of the 8 wt \% slurry with the Mott filter but not with the Graver filter.

- Changes in axial velocity of the slurry through the Mott and Graver filters did not significantly affect the filtrate flux with the dilute slurry.

- Statistically significant changes in filtrate flux were observed for the Mott but not the Graver filter with $8 \mathrm{wt} \%$ slurry when the axial velocity was varied. 


\section{Introduction}

The purpose of this filter study was to evaluate cross-flow filtration as effective solidliquid separation technology for treating Hanford wastes, outline operating conditions for equipment, examine the expected filter flow rates, and determine proper cleaning.

Two Hanford waste processing applications have been identified as candidates for the use of cross-flow filtration.' The first of the Hanford applications involves filtration of the decanted supernate from sludge leaching and washing operations. This process involves the concentration and removal of dilute $(0.05 \mathrm{wt} \%)$ fines from the bulk of the supernate. The second application involves filtration to wash and concentrate the sludge during outof-tank processing. This process employs a relatively concentrated (8 wt \%) solids feed stream.

Filter studies were conducted with simulants to evaluate whether 0.5 micron cross-flow sintered metal Mott filters and 0.1 micron cross-flow Graver filters can perform solidliquid separation of the solid/liquid waste streams effectively. In cross-flow filtration the fluid to be filtered flows in parallel to the membrane surface and generates shearing forces and/or turbulence across the filter medium. This shearing influences formation of a filter cake stabilizing the filtrate flow rate.

\section{$\underline{\text { Solid/Liquid Separation Method Selection }}$}

Although numerous solid/liquid separation technologies are commercially available, few are adaptable to high radiation fields. For example, the In-Tank Precipitation process at the Savannah River Site uses cross-flow filters made of seamless, sintered stainless steel. The filter elements are welded to the housing and contain no polymeric components. This design limits maintenance requirements to chemical cleaning, which can be done remotely. Cross-flow filters can concentrate slurries to relatively high weight loadings while maintaining filtrate production rates.

\section{Testing Strategy}

Laboratory filtration equipment is adequate for scoping activities identifying significant impacts to filter performance. Filtrate fluxes are generally higher with laboratory scale equipment than observed at production scale. Higher fluxes on small-scale equipment have been attributed to more effective backpulsing and chemical cleaning.

The accuracy and confidence of results obtained by use of simulated versus actual waste depend on several factors. Because these factors are not fully understood for filtration of sludge, comparisons are needed between simulants and actual waste. 


\section{Experimental}

\section{Simulant Preparation}

Simulants were developed at Pacific Northwest National Laboratory (PNNL) ${ }^{2}$ for testing of the cross-flow filtration processes. The composition of the simulants are shown in Table 1. The S-3 simulant represents Hanford waste and was developed to accurately reflect the physical properties, in particular the particle size, of the Tank C-103 Hanford waste. The simulant that contained $0.05 \mathrm{wt} \%$ insoluble solids represents supernate from the settled sludge while the $8.0 \mathrm{wt} \%$ simulant represents unwashed retrieved sludge.

Table 1 - Composition of Slurry S-3 (basis 26 liters)

$\begin{array}{lll}\text { Component } & \underline{\mathrm{S}-3,8.0 \mathrm{wt} \% \text { (mass, g) }} & \frac{\mathrm{S}-3,0.05 \mathrm{wt} \% \text { (mass, g) }}{11.7} \\ \begin{array}{l}\text { Boehmite } \\ \text { (Vista catapal D) }\end{array} & 2358 & 1.3 \\ \begin{array}{l}\text { Gibbsite } \\ \text { (Spacerite S-3) }\end{array} & 262.5 & \\ \mathrm{NaOH} & 120 & 104\end{array}$

Previous particle size distribution data have been collected on simulated waste samples. ${ }^{2}$ The samples were analyzed using a Microtrac II, Series 798 Particle Size Analyzer. The range of this instrument is 0.7 to 700 microns. The instrument operates via low-angle forward scattering of diode laser light. The samples were constantly mixed with a stirrer. Samples were analyzed immediately after introduction to the instrument and again after stirring for 20 minutes in the instrument. Three columns of data are presented in Table 2: the particle diameter below which 10,50 , and 90 volume percent of the particles lie. For example, for the S3-0.05 wt \% sample at 0 time $10 \%$ of the particles in the size are less than 1.21 microns, $50 \%$ of the particles are less than 4.46 microns, and $90 \%$ of the particles are less than 351.9 microns. The larger particle size of this sample indicates that agglomeration occurred for the $\mathrm{S} 3-0.05 \mathrm{wt} \%$ simulant at 0 time.

\section{Table 2 - Particle Size Data}

\begin{tabular}{|c|c|c|c|c|}
\hline$\underline{\text { Simulant }}$ & $\begin{array}{l}\text { Time } \\
\text { (mins) }\end{array}$ & $\begin{array}{l}10 \% \\
\text { (microns) }\end{array}$ & $\begin{array}{l}50 \% \\
\text { (microns) }\end{array}$ & $\begin{array}{l}90 \% \\
\text { (microns) }\end{array}$ \\
\hline S3-0.05 & 0 & 1.21 & 4.46 & 351.9 \\
\hline wt $\%$ & 20 & 0.95 & 1.91 & 4.25 \\
\hline S3-8.0 & 0 & 1.13 & 2.41 & 4.35 \\
\hline wt $\%$ & 20 & 1.13 & 2.39 & 4.26 \\
\hline
\end{tabular}

The above results indicate that the particle size was in the same range for both the S3-.05 wt $\%$ and $\mathrm{S} 3-8.0 \mathrm{wt} \%$ slurries. 
Rheology of the different slurries was measured using a Rotational Viscometer at different points of the filtration study. The results are given in Table 3.

Table 3 - Slurry Rheology Data

Slurry

Description

0.05 wt $\%$, Mott, Newtonian

$7 \mathrm{hr}$ filter time

0.05 wt $\%$, Mott, Newtonian

$11 \mathrm{hr}$ filter time

0.05 wt $\%$, Graver, Newtonian

$0 \mathrm{hr}$ filter time

0.05 wt $\%$, Graver, Newtonian

$8 \mathrm{hr}$ filter time

0.05 wt $\%$, Graver,

Newtonian

$10.5 \mathrm{hr}$ filter time

8 wt $\%$, Mott,

0 filter time

8 wt $\%$, Mott,

$0.5 \mathrm{hr}$ filter time

8 wt \%, Mott,

$8 \mathrm{hr}$ filter time

8 wt \%, Graver,

$0.5 \mathrm{hr}$ filter time

8 wt $\%$, Graver,

$6 \mathrm{hr}$ filter time

8 wt \%, Mott,

$0 \mathrm{hr}$ filter time (conc)

8 wt \%, Mott,

$5 \mathrm{hr}$ filter time (conc)

8 wt $\%$, Mott filter, Bingham

$7.5 \mathrm{hr}$ filter time (conc)

Bingham

Bingham

Bingham
Plastic Yield

Viscosity (cp) Viscosity (cp) Stress (dynes $/ \mathrm{cm}^{2}$ )

2.1

NA

NA

1.83

NA

NA

1.70

NA

NA

1.77

NA

NA

2.04

NA

NA

Newtonian $\quad 1.82$

NA

NA

Bingham NA

25.3

189.6

NA

31.2

335.5

NA

3.3

4.7

NA

22

87.6

Bingham NA

22

87.6

NA

69.1

888.4

NA

61.0

789.6 
Inspection of the rheology data in Table 3 shows that the viscosity remains relatively constant at around $2 \mathrm{cp}$ for the $0.05 \mathrm{wt}$ slurry, does not change if filters are changed, and does not seem to be affected by filtration time. Changes in viscosity are associated with changes in particle size caused by pump action shearing particles. Since the viscosity remains in the same range it seems that the dilute solution particles are not undergoing degradation. The rheology data exhibited the same behavior as a Newtonian fluid.

Before filtration, the $8 \mathrm{wt} \%$ slurry exhibited Newtonian type behavior with a viscosity of $1.82 \mathrm{cp}$. During the $8 \mathrm{wt} \%$ slurry Mott filtration the plastic viscosity stays nearly the same but yield stress increases with filtration time. The rheology data exhibited the same behavior as a Bingham plastic type fluid during the filtration. Since the viscosity increases with filtration time it is thought that the pump action is having a shearing effect on particle size which is causing the increase in viscosity.

During the $8 \mathrm{wt} \%$ slurry Graver filtration the plastic viscosity increases as does the yield stress with filtration time. The rheology data exhibited the same behavior as a Bingham plastic type fluid during the filtration. The same viscosity increase with filtration time is observed with the Graver filter as it was with the Mott. This indicates that the pumping action is having a shearing effect on particle size which is causing the increase in viscosity.

During the $8 \mathrm{wt} \%$ slurry concentration with a Mott filter the plastic viscosity increases as does the yield stress with filtration time. The rheology data exhibited the same behavior as a Bingham plastic type fluid during this time. Since the concentration is increasing with filtration time the increase in viscosity could not only be caused by shear but also from the thickening of the slurry because of increasing wt \%.

\section{Cross-Flow Filter Operating Conditions}

Cross-flow filtration experiments were performed with each of these simulants using the Parallel Rheology Experimental Filter (PREF) shown in Figure 1. Each test involved measuring the filtrate flux under a variety of conditions. The two independent variables for these tests were filter transmembrane pressure drop and axial velocity. The test settings of variables were determined using a statistical model to cover low, high, and intermediate points of the variable ranges. The order of the variable settings was also varied to minimize experimental errors associated with taking data points of the same range during the same time period. Transmembrane pressure drop is defined as the sum of slurry pressure entering and exiting the filter divided by 2 minus the pressure of the filtrate as it leaves the filter. Axial velocity is defined as the speed that the slurry is moving inside the filter. The conditions for the test are listed in Table 4. A backpulse was performed following each change in the test parameters. Measurements were taken at each test condition for a period of 1 hour. Following the completion of each test, a statistical analysis determined the dependence of filtrate flux for those test conditions as a function of transmembrane pressure drop and axial velocity. An additional analysis was 
performed to determine the dependence of filter performance on time (as an indication of filter fouling).

Table 4 - Test settings

$0.05 \mathrm{Wt} \%$ slurry filtration

Setting Number

1,6

2

3

4

5

7

8

9

10

11

\begin{tabular}{ll} 
Transmembrane pressure (psi) & Velocity (ft/s) \\
\cline { 2 - 2 } 20 & 3.6 \\
27.5 & 4.5 \\
20 & 1.8 \\
5 & 3.6 \\
12.5 & 4.5 \\
5 & 2.7 \\
12.5 & 3.6 \\
20 & 5.4 \\
27.5 & 2.7 \\
35 & 3.6
\end{tabular}

$8 \mathrm{Wt} \%$ slurry filtration Setting Number 1

2

3

4

5

6

7

8

9

10

11
Transmembrane pressure (psi) 25

32.5

25

10

17.5

25

32.5

40

25

17.5

25
Velocity (ft/s)

3.6

4.5

1.8

3.6

4.5

3.6

2.7

3.6

5.4

2.7

3.6

\section{Equipment Description}

The Mott and Graver cross-flow filters are seamless tubes fabricated by the manufacturers by sintering 316 stainless steel particles. The Mott filter, manufactured by Mott Metallurgical Corporation of Farmington, Conn. has a 0.5 inch inner diameter, is 4 feet long, and has 0.5 micron pores. The Graver filter, manufactured by Graver Separations, of Glasgow, Delaware has a .625 inch inner diameter, is 2.5 feet long, has 0.1 micron pores, and has a layer of titania. A Moyno progressive cavity positive displacement pump manufactured by Moyno Industrial Products of Springfield, Ohio provided slurry flow. The Parallel Rheological Experimental filter apparatus and associated equipment used in the filtration study is shown in Sketch 1. 
Sketch 1.

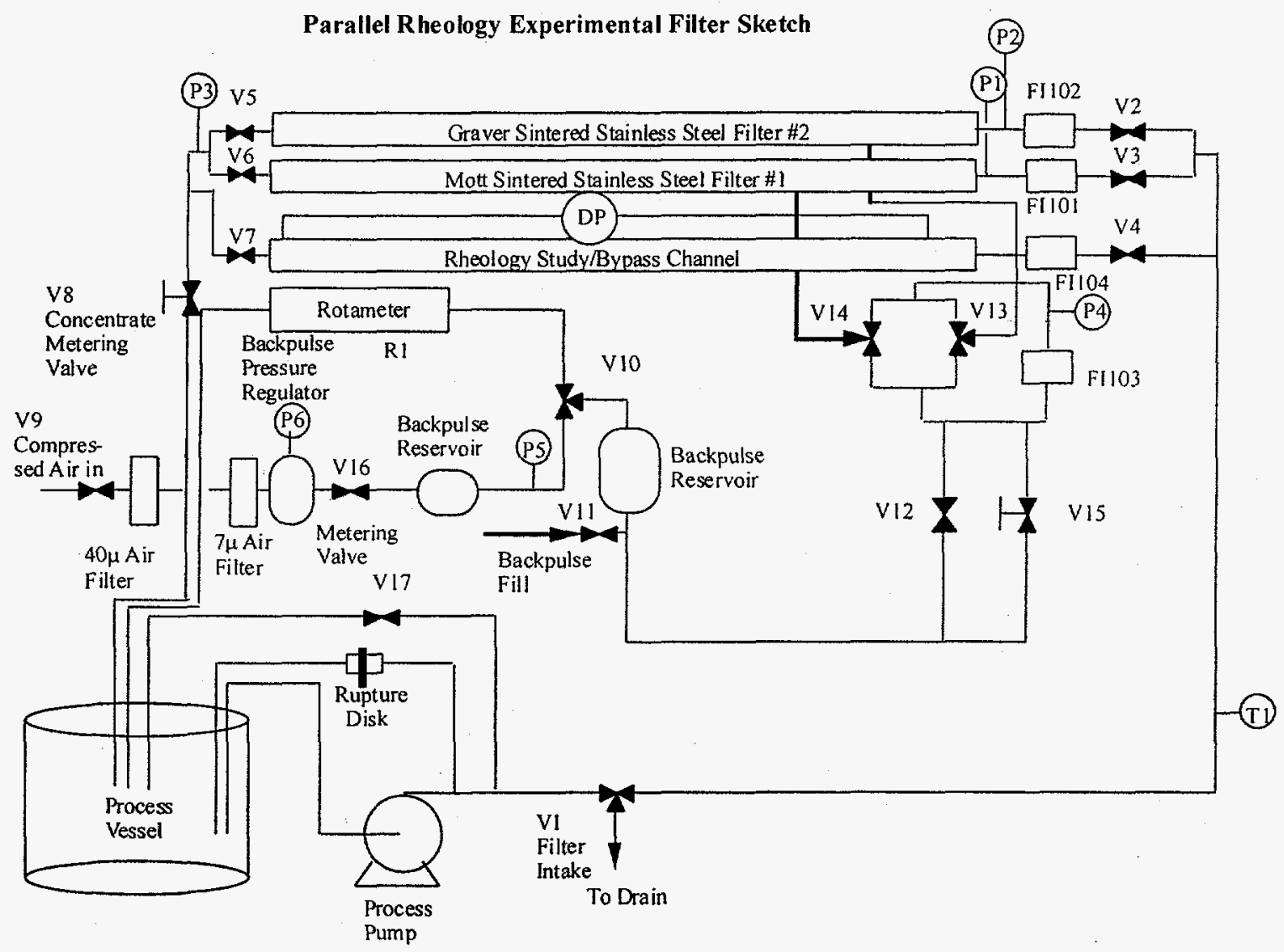




\section{Filtration Mechanism}

In cross-flow filtration the fluid to be filtered flows in parallel to the membrane surface and generates shearing forces and/or turbulence across the filter medium which influences formation of a filter cake or particle deposition in filter pores.

Cross-flow filtration can be separated into two areas of operation. ${ }^{3}$ In the first area of operation, the axial velocity is sufficient to remove any solids from the surface of the filter. Thus, there is not an accumulation of filter cake on the surface of the filter and any decrease in filter performance is attributed to the deposition of solids within the filter pores. This area of operation is usually associated with dilute feed streams, high axial velocities and low pressure drops. Under these conditions, increasing the axial velocity of the feed stream concentration will have little impact on filtrate production rates. However, increases in transmembrane pressure drop will produce significant increases in filtrate flow rates. This increase in filtrate flow rate with transmembrane pressure drop was seen with the dilute $0.05 \mathrm{wt} \%$ slurry using both the Mott filter and the Graver filter indicating deposition of solids in the filter pores of the filters. The significant increase in filtrate flow rate with transmembrane pressure drop was also seen during filtration of the $8 \mathrm{wt} \%$ slurry with the Mott filter but not with the Graver filter. This indicates deposition of solids in the filter pores of the Mott but not in the Graver filter at the higher $8 \mathrm{wt} \%$ slurry.

In the second area of operation, normally when more concentrated feed streams are employed (greater than $5 \mathrm{wt} \%$ solids), a higher axial velocity is needed to keep the surface of the filter free of deposited solids. If the axial velocity is not sufficient, a cake of solids will deposit on the surface of the filter. Under these conditions, an increase in the axial velocity will increase the rate of transport of solids from the surface of the filter, and thus decrease the thickness of the filter cake, producing an increase in filter performance. The surface filter cake will cause a decrease in filter performance when an excessive thickness of filter cake is deposited.

If filtrate flux varies significantly with velocity this indicates filter cake formation on the filter surface and no deposition of solids into the pores. Filter cake formation is indicated with the Mott filtration of the $8 \mathrm{wt} \%$ slurry since the filtrate flow rate was significantly affected by the axial velocity of the slurry. This effect was not observed filtering the $8 \mathrm{wt}$ $\%$ slurry with the Graver filter. A filter cake was not formed in the dilute $0.05 \mathrm{wt} \%$ slurry with either filter since changes in axial velocity of the slurry through the filters did not significantly affect the filtrate flow rate. 


\section{Filtration Results}

Prior to testing, the $8 \mathrm{wt} \% \mathrm{~S}-3$ simulant settled extensively. This simulant contained primarily boehmite alumina. After filtration testing, the $8 \mathrm{wt} \% \mathrm{~S}-3$ simulant did not settle. Furthermore, filtrate flow rate for this filtration test was low. These results indicate that the particles experienced large amounts of shear and were degraded during the process of testing, causing low flow rates.

The results of the experiments are shown in Figures 1 through 15. Figure 1 contains a plot of the Mott filtrate flux for the $0.05 \mathrm{wt} \%$ simulant as a function of time. Single variable statistical analysis of this data using linear regression shows the filtrate flux is not dependent on time therefore filter fouling is not occurring. Note that these predictions are valid only over the range of operating conditions outlined in Table 1 in the experimental section. The large spikes in filtrate flux correspond to backpulsing of the filter.

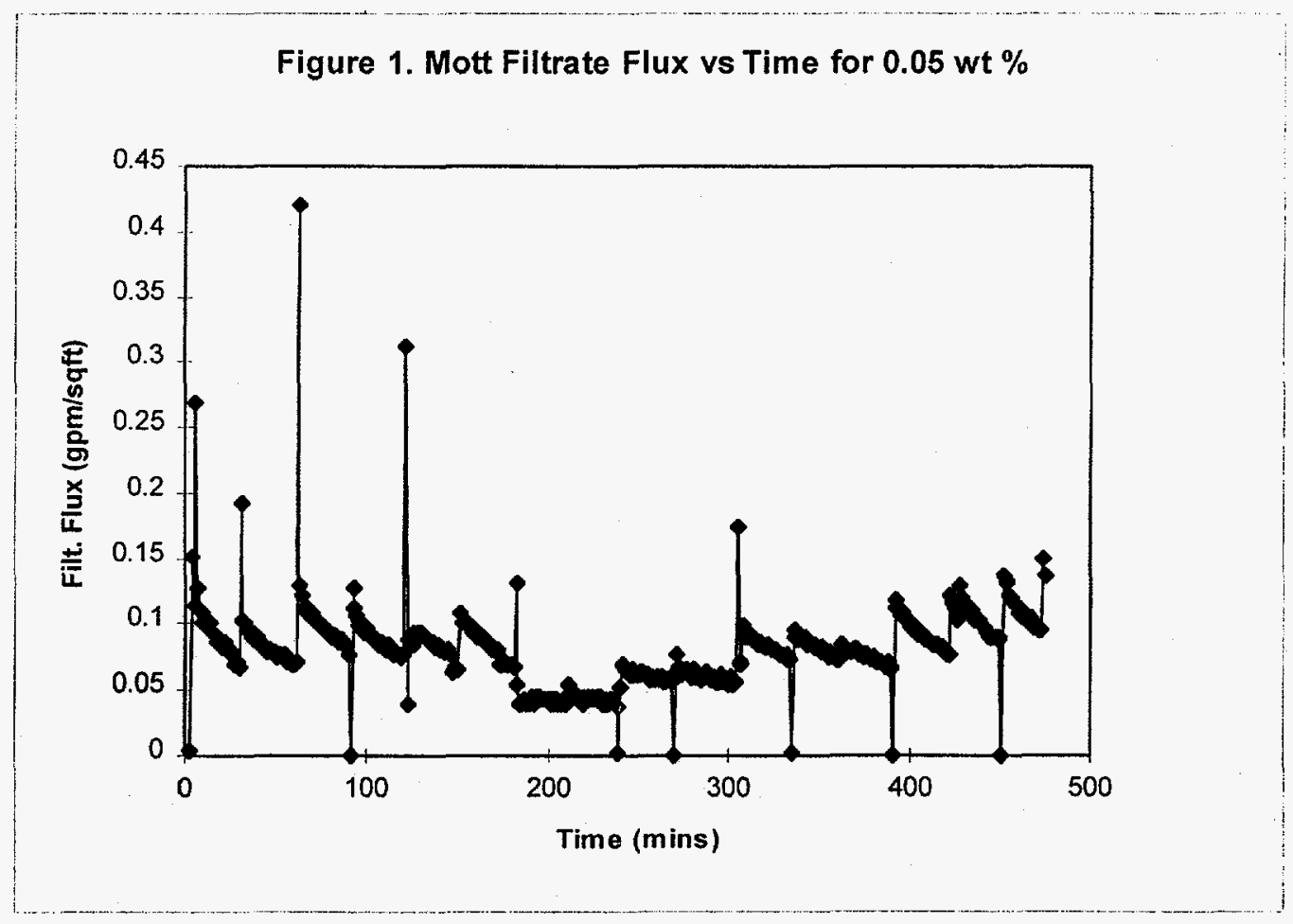


Figure 2 contains a plot of filtrate flux as a function of pressure drop for the slurry showing that an increase in filter pressure drop gives a significant increase in filter performance. The statistical analysis linear model developed from linear regression predicts filtrate flux is dependent on filter differential pressure. This indicates deposition of sub-surface solids in the pores. The statistical model for the filtrate flux and DP is

$\mathrm{Q}=0.001625 \mathrm{DP}+0.0302$

where $\mathrm{Q}=$ filtrate flux $\left(\mathrm{gpm} / \mathrm{f}^{\mathrm{f}}\right)$ and $\mathrm{DP}=$ Transmembrane Differential Pressure (psi)

The $95 \%$ confidence interval for the filter transmembrane differential pressure coefficient is $0.00205<\mathrm{c} 1<0.0012$.

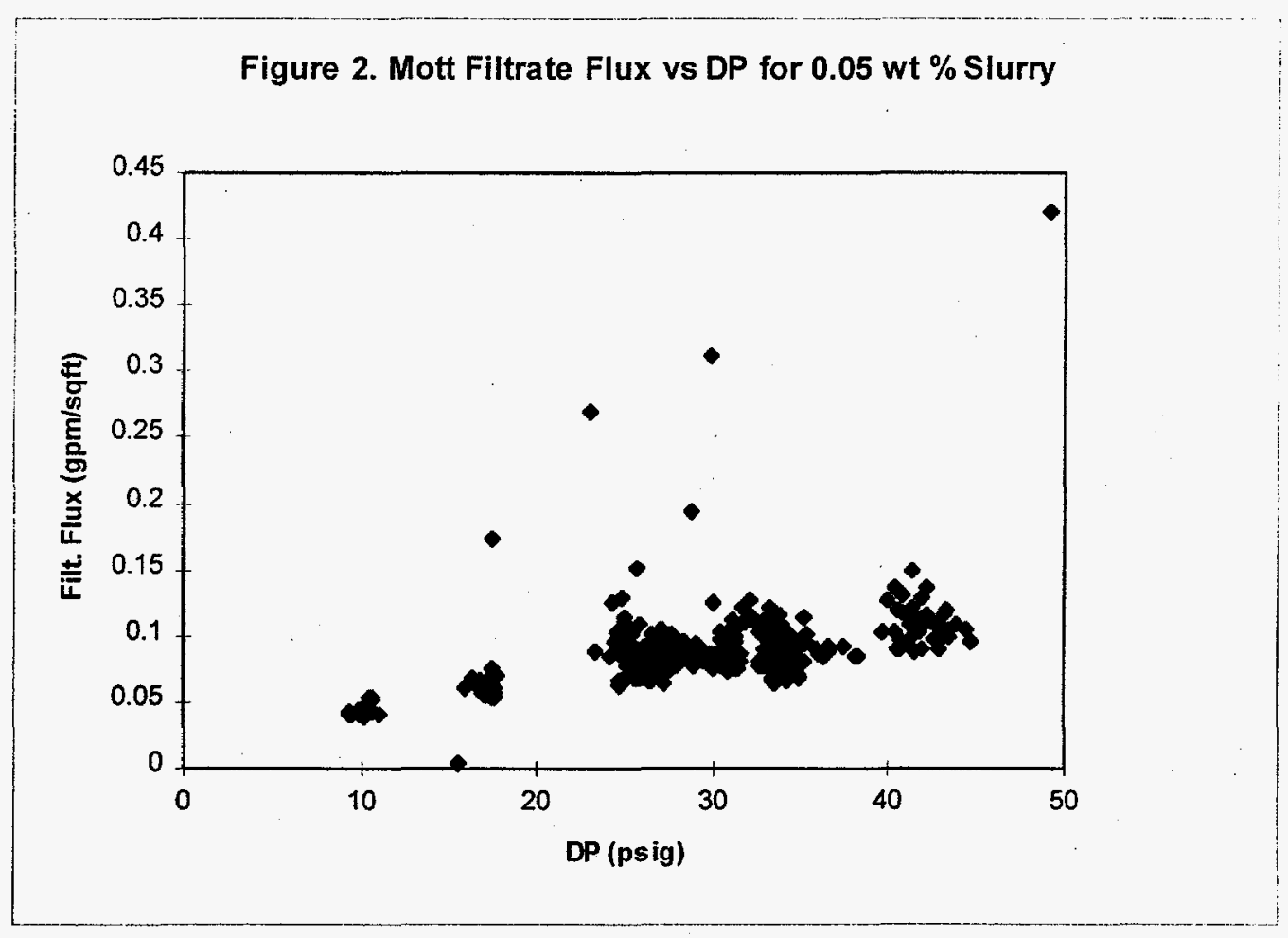


Figure 3 is a plot of the filtrate flux versus the axial velocity. Linear regression of the data predicts that filtrate production does not decrease significantly with axial velocity. This indicates that a filter cake is not being formed on the filter surface and back transport of material from the surface of the filter is not dictating filtrate flux.

Figure 3. Mott Filtrate Flux vs Axial Velocity for 0.05 wt $\%$

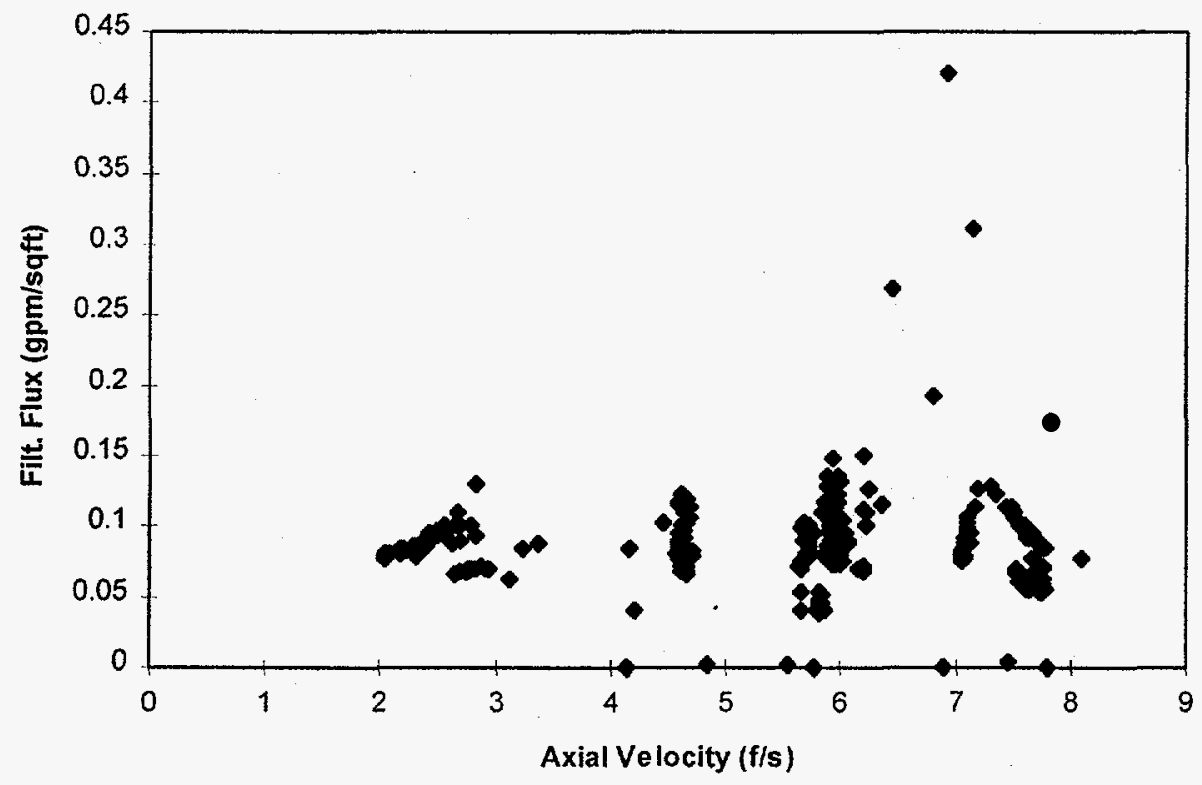


Figure 4 is a plot of the Graver filtrate flux of $0.05 \mathrm{wt} \%$ slurry versus the time. Linear regression analysis of the data indicates that filtrate production does not decrease significantly with time. If this is the case fouling of the filter is not occurring.

Figure 4. Graver Filtrate Flux vs Time for 0.05 wt \% Slurry

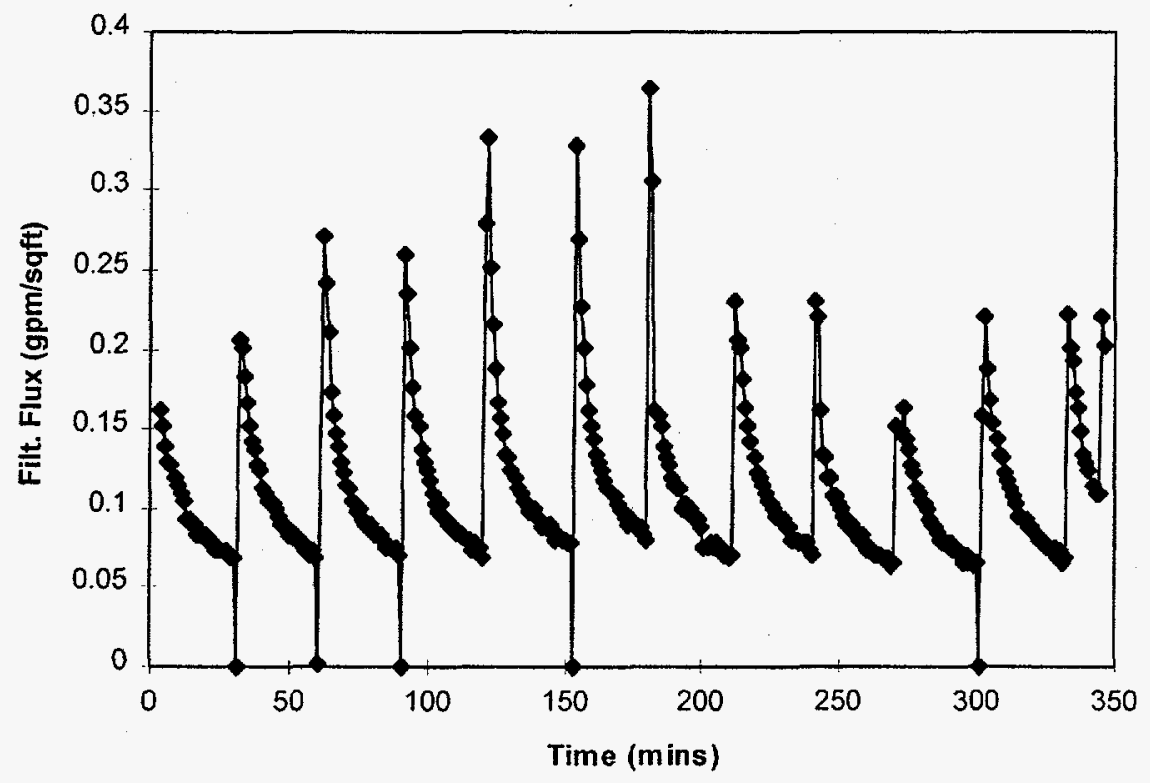


Figure 5 contains a plot of Graver filtrate flux of the $0.05 \mathrm{wt} \%$ slurry as a function of transmembrane pressure drop. Linear regression analysis of the data indicates that an increase in filter transmembrane pressure drop gives a significant increase in filter performance. Thus there is formation of sub-surface solids in the pores. The linear regression model is

$\mathrm{Q}=0.000809 \mathrm{DP}+0.0637$

where $\mathrm{Q}$ is the filtrate flux and DP is the transmembrane pressure drop. The $95 \%$ confidence interval for the DP coefficient is $0.00114<\mathrm{cl}<0.000476$.

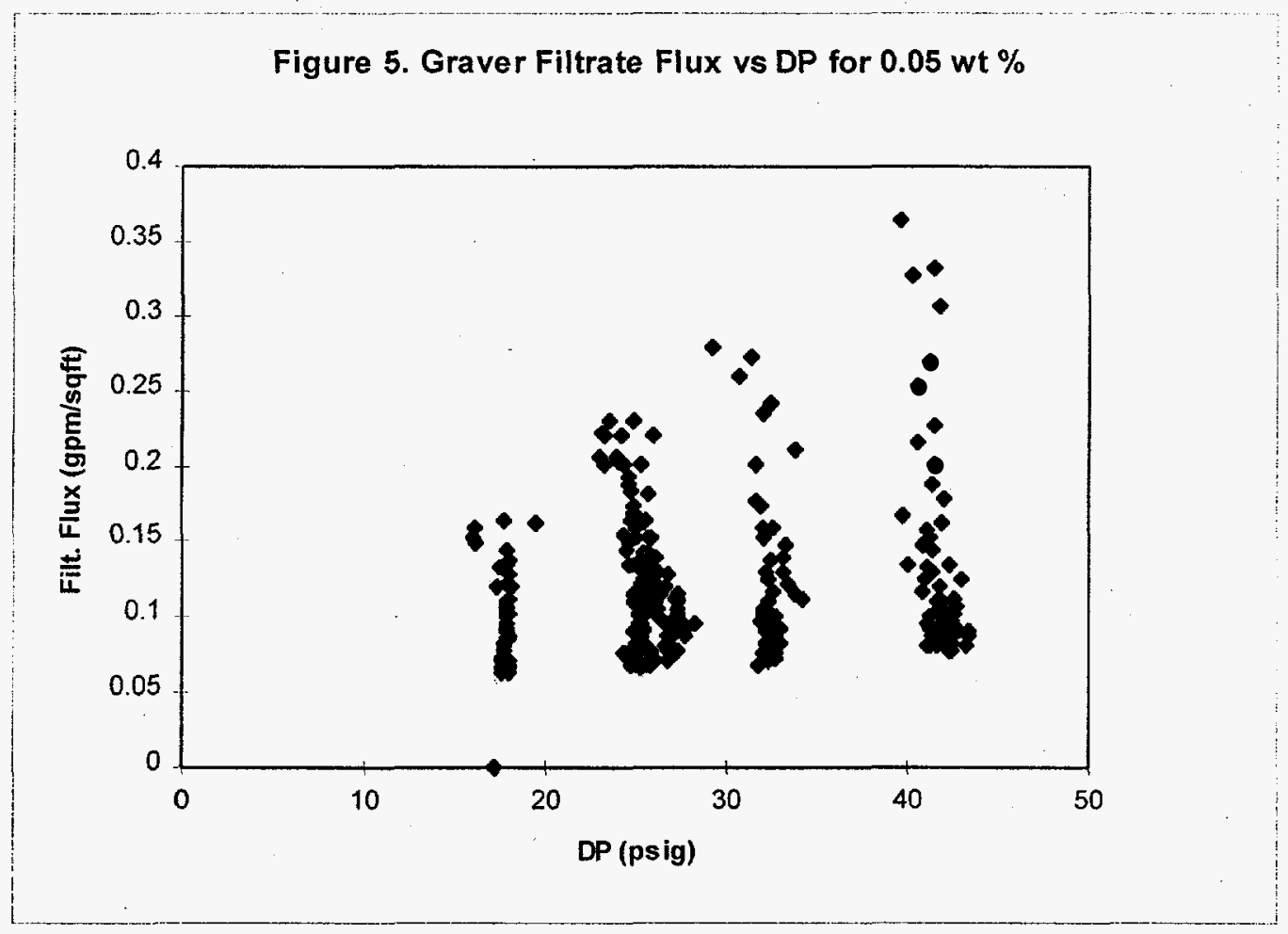


Figure 6 contains a plot of the Graver filtrate flux for the $0.05 \mathrm{wt} \%$ slurry as a function of axial velocity. Single variable statistical analysis of this data using linear regression shows the filtrate flux is not dependent on axial velocity. This indicates that a surface filter cake is probably not developed and back transport of material from the surface of the filter is not dictating filtrate flux.

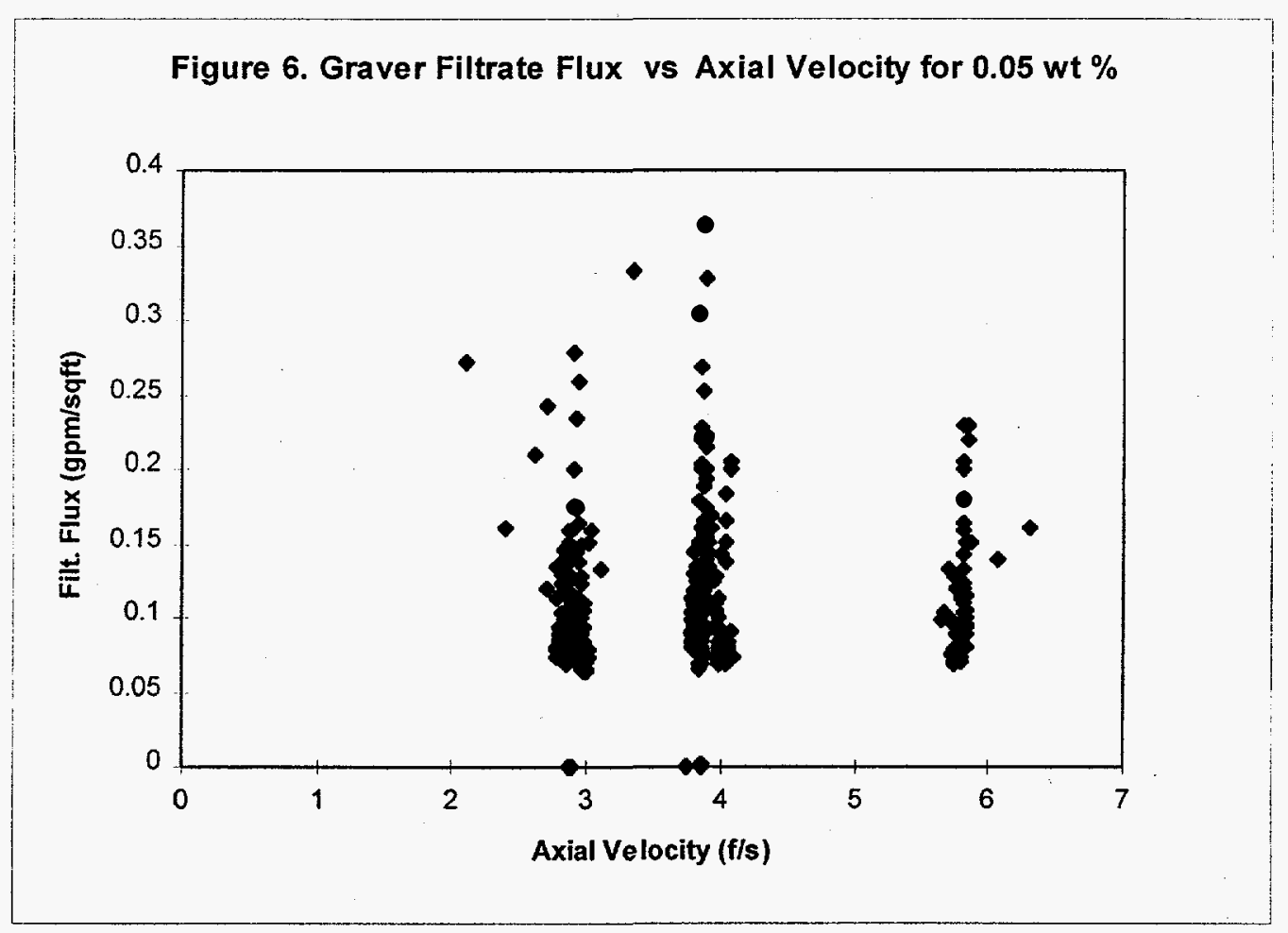


Figure 7 is a plot of the Mott filtrate flux of $8 \mathrm{wt} \%$ slurry versus time. Linear regression analysis of the data predicts that filtrate production does not decrease significantly with time indicating fouling of the filter is not occurring.

Figure 7. Mott Filtrate Flux vs Time for 8 wt \% Slurry

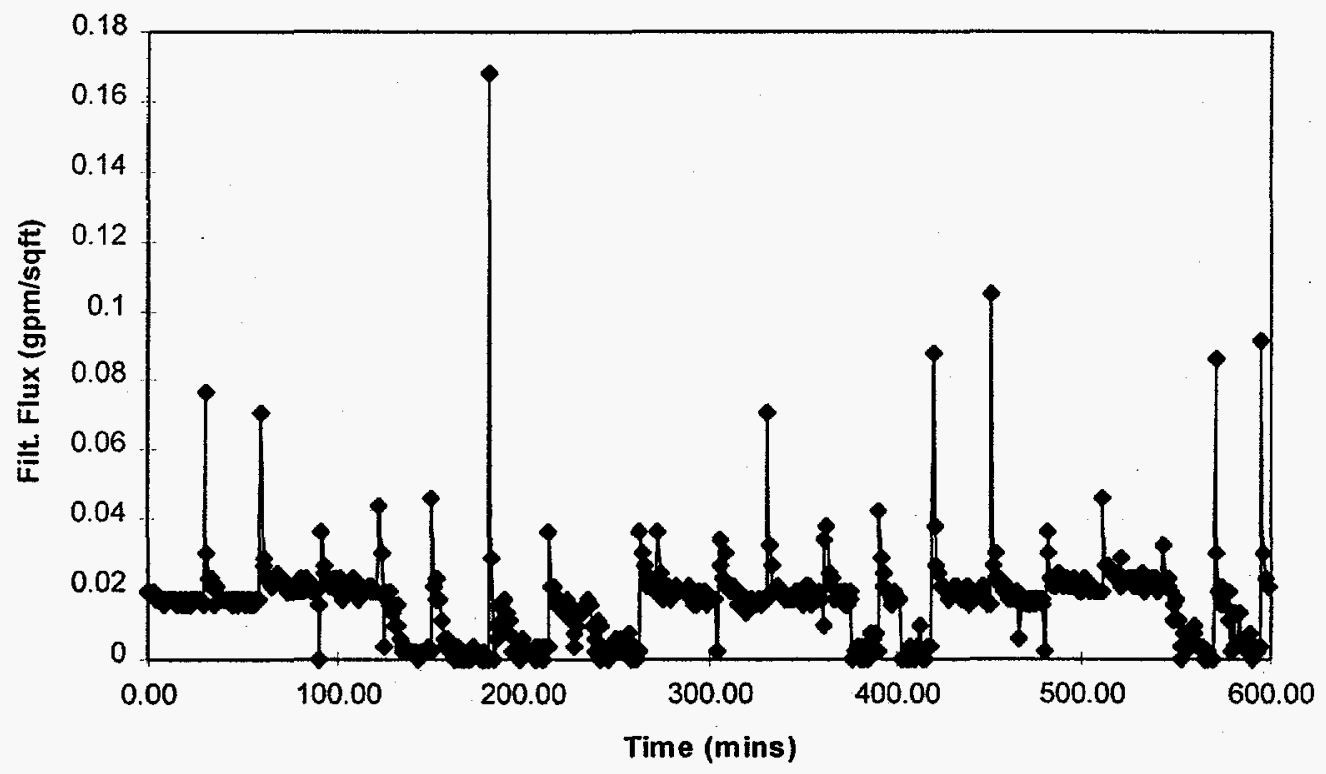


WSRC-TR-97-00353

Page 17 of 28

Figure 8 contains a plot of Mott filtrate flux of the $8 \mathrm{wt} \%$ slurry as a function of transmembrane pressure drop. The statistical analysis linear model developed from linear regression predicts filtrate flux is dependent on filter transmembrane differential pressure drop indicating that there is deposition of solids in the pores. The statistical model predicted is

$\mathrm{Q}=0.00034 \mathrm{DP}+0.00897$

where $\mathrm{Q}$ is the filtrate flux and $\mathrm{DP}$ is the transmembrane differential pressure. The $95 \%$ confidence interval for the DP coefficient is $0.000633<\mathrm{c} 1<4.67 \mathrm{e}-5$.

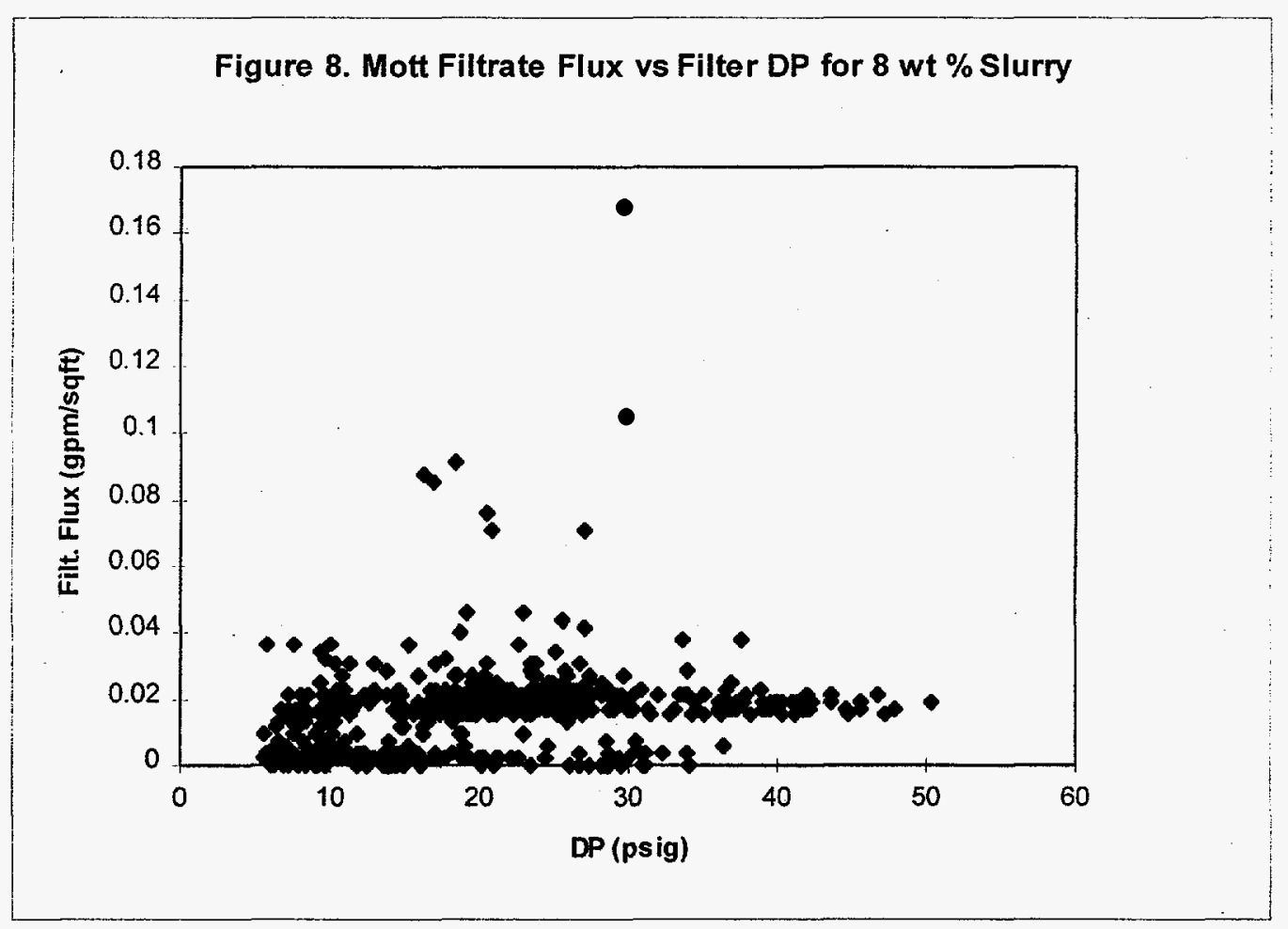


Figure 9 contains a plot of the Mott filtrate flux for the $8 \mathrm{wt} \%$ slurry as a function of axial velocity. Linear regression of this data indicates that filtrate flux increases statistically in response to increases in axial velocity. This suggests that a filter cake is formed on the surface and back transport of material from the surface of the filter cake is dictating filtrate flux.

The statistical model predicted is

$Q=0.00194 \mathrm{~V}+0.00461$

where $\mathrm{Q}$ is the filtrate flux and $\mathrm{V}$ is the axial velocity. The $95 \%$ confidence interval for the $\mathrm{V}$ coefficient is $0.00359<\mathrm{cl}<0.00029$.

Filtrate flux of $8 \mathrm{wt} \%$ slurry seemed to be slightly higher with the Mott filter and stopped completely several times during the Graver filtration process therefore the Mott filter was chosen as the filter to concentrate the $8 \mathrm{wt} \%$ slurry.

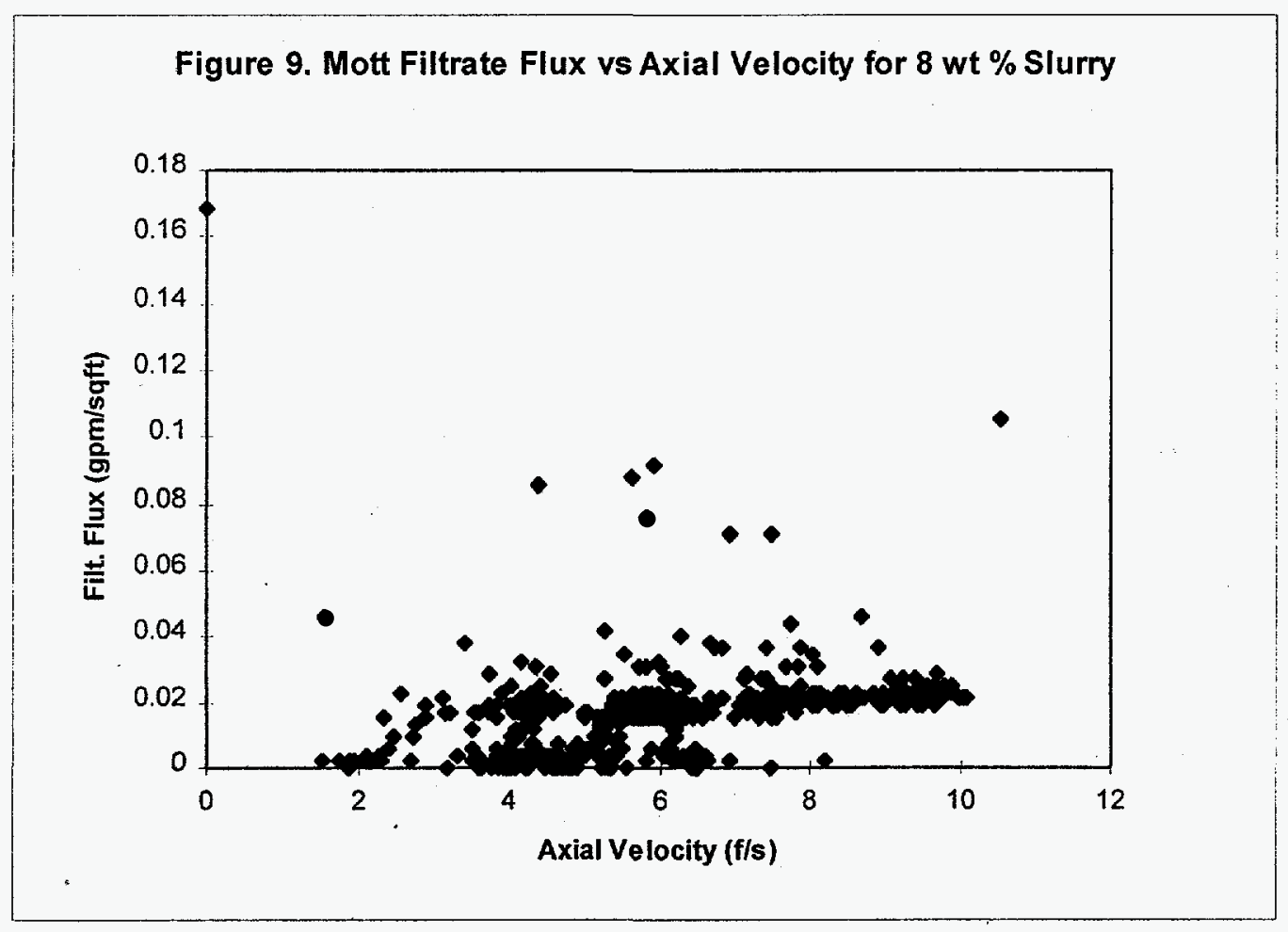


Figure 10 is a plot of the Graver filtrate flux of $8 \mathrm{wt} \%$ slurry versus time. Linear regression analysis of this data shows that filtrate production does not decrease significantly with time indicating fouling of the filter is not occurring. However, the filtrate flux for this filter is very low and becomes zero a large part of the time.

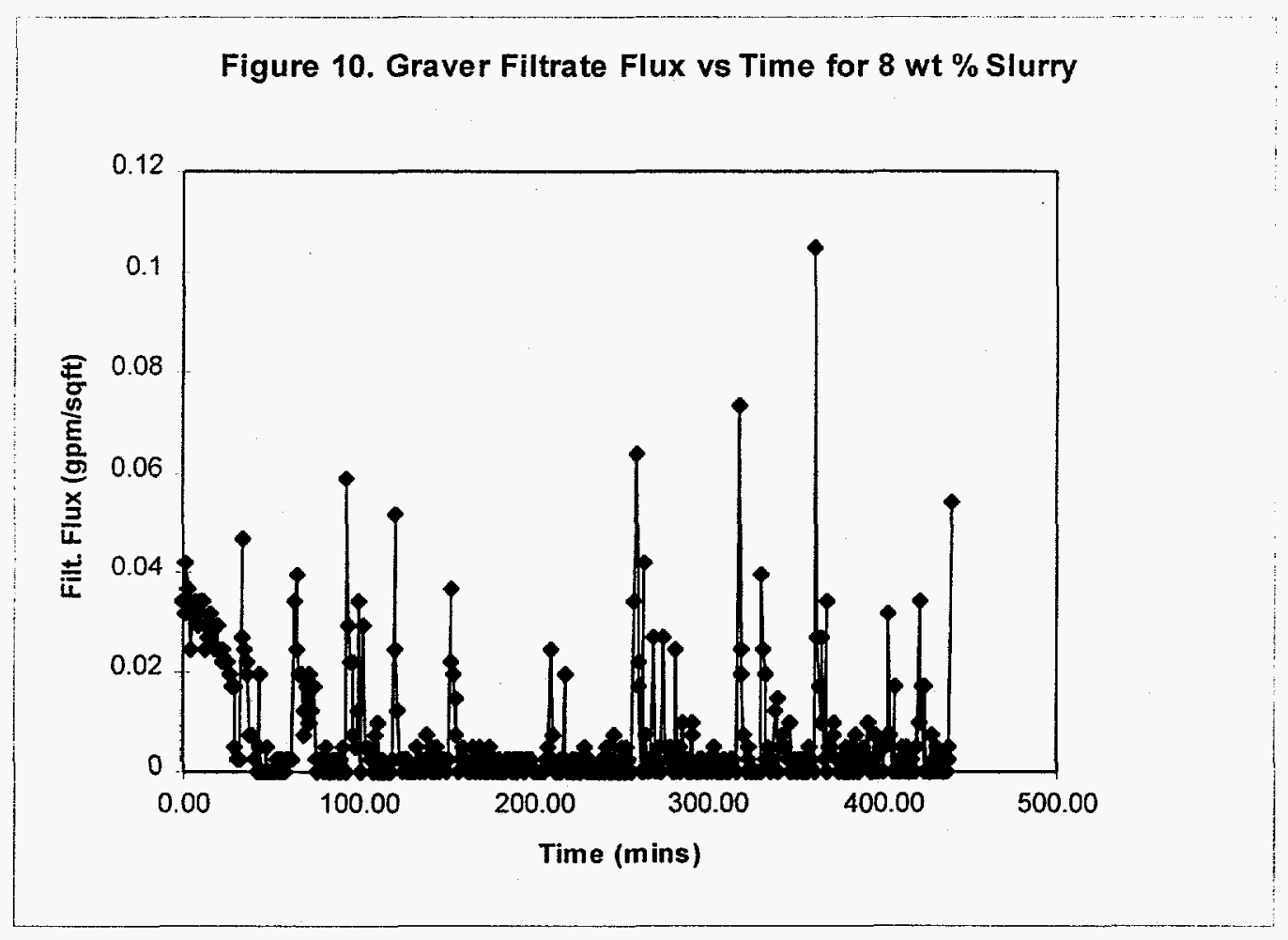


Figure 11 contains a plot of Graver filtrate flux of the $8 \mathrm{wt} \%$ slurry as a function of transmembrane pressure drop. Linear regression analysis of the data predicts filtrate flux is independent of filter transmembrane differential pressure therefore there is no solids deposition in the pores.

Figure 11. Graver Filtrate Flux vs DP for 8 wt \%

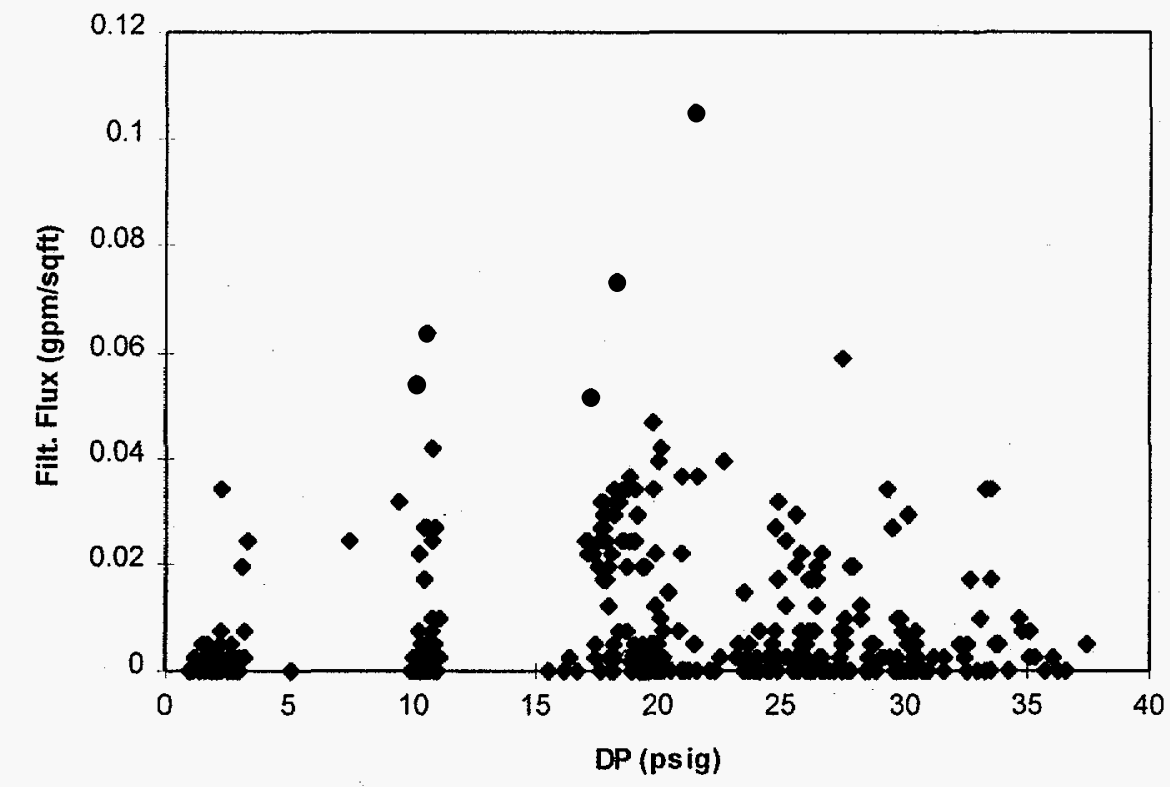


WSRC-TR-97-00353

Page 21 of 28

Figure 12 contains a plot of the Graver filtrate flux for the $8 \mathrm{wt} \%$ slurry as a function of axial velocity. Linear regression analysis of this data shows that filtrate flux does not increase statistically in response to increases in axial velocity thus a surface filter cake is probably not developed. If a filter cake is not developed then back transport of material from the surface of a filter cake affecting filtrate flux is not possible.

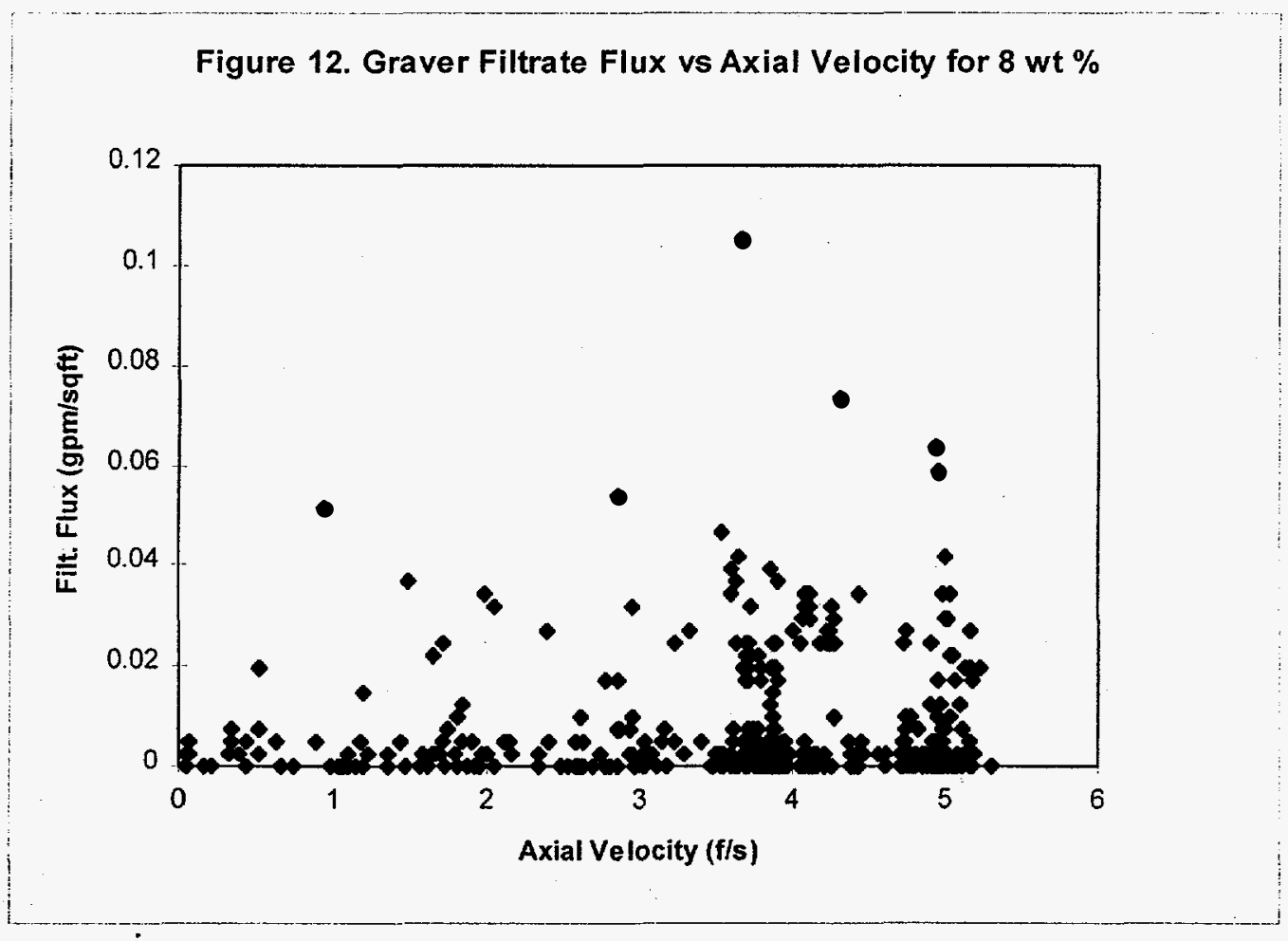


Figure 13 contains a plot of the Mott filtrate flux for the $8 \mathrm{wt} \%$ slurry during concentration to $14.5 \mathrm{wt} \%$ as a function of time. The concentration of the slurry was performed to determine the maximum weight per cent solids that could be used for filtration. Linear regression analysis of this data indicates that filtrate flux does not increase statistically in response to increases in time therefore fouling of the filter is not occurring.

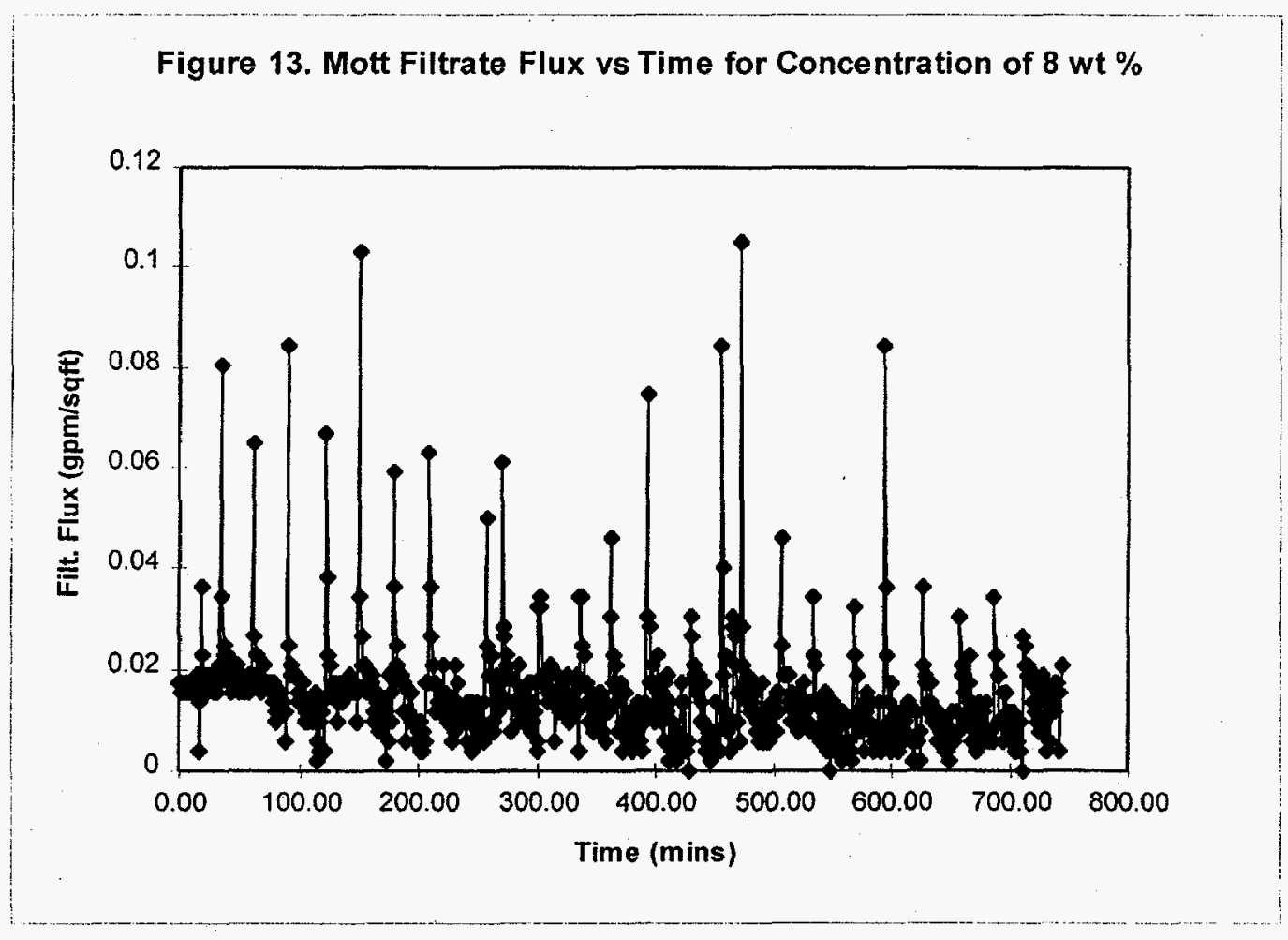


Upon conclusion of the filter test, a cleaning step was employed. During this step, all the slurry was removed from the process vessel and process lines. These lines were then flushed three times in a once through pass. The process vessel was then filled with inhibited $(\mathrm{pH} \mathrm{10)}$ water that was recirculated for a period of 1 hour with periodic backpulses. Following this, the process vessel was again drained and refilled with $2 \mathrm{wt} \%$ oxalic acid.

The oxalic acid solution was then circulated through the process loop for 60 minutes with periodic backpulses. Following 2 additional flushes with inhibited water, this process was repeated with a $2 \mathrm{wt} \% \mathrm{NaOH}$ solution with periodic backpulses. A measurement of the clean water flux was conducted and the oxalic acid, water, and $\mathrm{NaOH}$ treatments repeated until the measured flux was $80 \%$ of the values listed in the vendor literature (See Table 5 and 6).

\section{Table 5 - Clean Water Flux Before Filtration}

Mott Filter

$\begin{array}{llllll}\begin{array}{l}\text { Filter Inlet } \\ \text { Pressure } \\ \text { (psig) }\end{array} & \begin{array}{l}\text { Filter Outlet } \\ \text { Pressure } \\ \text { (psig) }\end{array} & \begin{array}{l}\text { Filtrate } \\ \text { Pressure } \\ \text { (psig) }\end{array} & \begin{array}{l}\text { Vendor Flux } \\ \text { Clean Flux } \\ \text { (Gal/hr) }\end{array} & \begin{array}{l}\text { Actual } \\ \text { Flux } \\ \text { (Gal/hr) }\end{array} & \text { \% Clean } \\ 10 & 10 & 5.03 & 26 & 23 & 88.5 \\ 20 & 20 & 10.7 & 32 & 29 & 90.6 \\ 30 & 30 & 16.7 & 40 & 36 & 90.0 \\ 35 & 35 & 18.4 & 44 & 38 & 86.4 \\ 25 & 25 & 13.5 & 40 & 32 & 80.0 \\ 15 & 15 & 7.9 & 32 & 26 & 81.3\end{array}$

Graver Filter

$\begin{array}{llllll}\begin{array}{l}\text { Filter Inlet } \\ \text { Pressure } \\ \text { (psig) }\end{array} & \begin{array}{l}\text { Filter Outlet } \\ \text { Pressure } \\ \text { (psig) }\end{array} & \begin{array}{l}\text { Filtrate } \\ \text { Pressure } \\ \text { (psig) }\end{array} & \begin{array}{l}\text { Vendor Flux } \\ \text { Clean Flux } \\ \text { (Gal/hr) }\end{array} & \begin{array}{l}\text { Actual } \\ \text { Flux } \\ \text { (Gal/hr) }\end{array} & \text { \% Clean } \\ 10 & 10 & 0.26 & 3.52 & 2.88 & 81.9 \\ 20 & 20 & 0.4 & 6.72 & 5.52 & 82.1 \\ 30 & 30 & 0.62 & 10.08 & 7.98 & 79.2 \\ 35 & 35 & 0.85 & 11.88 & 9.30 & 78.3 \\ 25 & 25 & 0.52 & 8.52 & 7.14 & 83.8 \\ 15 & 15 & 0.30 & 5.04 & 4.20 & 83.3\end{array}$


WSRC-TR-97-00353

Page 24 of 28

Table 6 - Clean Water Flux After Filtration and Cleaning

Mott Filter

$\begin{array}{llllll}\begin{array}{l}\text { Filter Inlet } \\ \begin{array}{l}\text { Pressure } \\ \text { (psig) }\end{array}\end{array} & \begin{array}{l}\text { Filter Outlet } \\ \text { Pressure } \\ \text { (psig) }\end{array} & \begin{array}{l}\text { Filtrate } \\ \text { Pressure } \\ \text { (psig) }\end{array} & \begin{array}{l}\text { Vendor Flux } \\ \text { Clean Flux } \\ \text { (Gal/hr) }\end{array} & \begin{array}{l}\text { Actual } \\ \text { Flux } \\ \text { (Gal/hr) }\end{array} & \text { \% Clean } \\ 10 & 10 & 5.0 & 21 & 23 & 80.7 \\ 20 & 20 & 10.9 & 29 & 29 & 80.6 \\ 30 & 30 & 16.4 & 40 & 35 & 87.5 \\ 35 & 35 & 17.3 & 44 & 36 & 81.8 \\ 25 & 25 & 14.0 & 40 & 33 & 82.5 \\ 15 & 15 & 7.9 & 32 & 27 & 84.4\end{array}$

Graver Filter

$\begin{array}{llllll}\begin{array}{l}\text { Filter Inlet } \\ \text { Pressure } \\ \text { (psig) }\end{array} & \begin{array}{l}\text { Filter Outlet } \\ \text { Pressure } \\ \text { (psig) }\end{array} & \begin{array}{l}\text { Filtrate } \\ \text { Pressure } \\ \text { (psig) }\end{array} & \begin{array}{l}\text { Vendor Flux } \\ \text { Clean Flux } \\ \text { (Gal/hr) }\end{array} & \begin{array}{l}\text { Actual } \\ \text { Flux } \\ \text { (Gal/hr) }\end{array} & \text { \% Clean } \\ 10 & 10 & 0.26 & 3.52 & 2.83 & 80.3 \\ 20 & 20 & 0.4 & 6.72 & 5.59 & 83.3 \\ 30 & 30 & 0.62 & 10.08 & 8.40 & 82.5 \\ 35 & 35 & 0.85 & 11.88 & 9.46 & 79.6 \\ 25 & 25 & 0.52 & 8.52 & 6.93 & 81.3 \\ 15 & 15 & 0.30 & 5.04 & 4.24 & 84.2\end{array}$


Analyses of filtrate samples taken during all types of slurries and filters gave acceptable clear filtrate with turbidity results all below 2 Nephelometric Turbidity Units (see Table 7).

Table 7 Turbidity of Filtrate Samples

$\underline{\text { Description }}$

Stray light standard

1.8 NTU standard

$8 \mathrm{wt} \%$ filtrate, Mott, $.5 \mathrm{hrs}$

$8 \mathrm{wt} \%$ filtrate, Graver, $.5 \mathrm{hrs}$

$0.05 \mathrm{wt} \%$ filtrate, Mott, $7 \mathrm{hrs}$

$0.05 \mathrm{wt} \%$ filtrate, Mott, $11 \mathrm{hrs}$

8 wt $\%$ filtrate, Graver, 6 hrs

$8 \mathrm{wt} \%$ filtrate, Mott, $8 \mathrm{hrs}$

$8 \mathrm{wt} \%$ filtrate, Mott, $7.5 \mathrm{hrs}$

$0.05 \mathrm{wt} \%$ filtrate, Graver, 0 hrs

$0.05 \mathrm{wt} \%$ filtrate, Graver, $10.5 \mathrm{hrs}$

0.05 wt $\%$ filtrate, Graver, 8 hrs

Stray light standard

1.8 NTU standard

\section{Nephelometric Turbidity Units}

.004

1.806

1.69

1.49

1.53

1.62

1.89

1.64

1.44

1.51

1.23

1.25

.002

1.813

\section{Conclusions}

Graver cross-flow filters have been shown to give higher filtrate flux than the Mott filter for the $0.05 \mathrm{wt} \%$ slurry. Mott cross-flow filtration gives higher filtrate flux than the Graver filters for the $8 \mathrm{wt} \%$ slurry. Analyses of filtrate samples taken during all types of slurries and filters gave acceptable clear filtrate. Filter cleaning of the Mott and Graver cross-flow filters after filtration was achieved using $2 \mathrm{wt} \%$ sodium hydroxide solution and $2 \mathrm{wt} \%$ oxalic acid solution.

The filtrate flux was not statistically significant with respect to axial velocity for either the Mott type of filter or the Graver type of filter for the $0.05 \mathrm{wt} \%$ slurry indicating a filter cake is not formed on the surface of the filter for these cases and that the axial velocity is sufficient to keep the surface free of filter cake. A filter cake is formed on the filter surface observed for the Mott filter with $8 \mathrm{wt} \%$ slurry because statistically significant changes in filtrate flux were observed when the axial velocity was varied. 
The filtrate flux was statistically significant with respect to filter transmembrane differential pressure for the Mott and Graver filter when filtering $0.05 \mathrm{wt} \%$ slurry. The filtrate flux was also affected significantly by the transmembrane differential pressure during the Mott filtration of the $8 \mathrm{wt} \%$ slurry. The filtrate flux being statistically significant with respect to filter differential pressure indicates deposition of solids in the pores of the filter but not on the filter surface and that back-transport of slurry particles is not the dominating filtration mechanism. This type of filter mechanism would not be affected by increases in axial velocity because a filter cake would not be exposed to the bulk slurry flow. Since there is no cake on the filter surface, back transport of rejected slurry particles should not play a role in filter performance. Also there should not be any boundary layer interactions because a boundary layer can only form on filter cakes located on the filter surface not in the pores.

Filter fouling indicated by a statistical significance of filtrate flux with increasing time does not seem to occur for either of the filters for the $0.05 \mathrm{wt} \%$ or the $8 \mathrm{wt} \%$ slurry. Filter fouling was also not observed when the $8 \mathrm{wt} \%$ slurry was concentrated. However, there was an alarming amount of low filtrate flow rates near zero obtained with the Graver filter during the $8 \mathrm{wt} \%$ filtration. For this reason the Mott filter was chosen to concentrate the $8 \mathrm{wt} \%$ slurry to a maximum concentration of $14.5 \mathrm{wt} \%$.

Comparison of these results with those obtained by PNNL researchers using actual waste ${ }^{4}$ indicate that this simulant behaves most like tank $\mathrm{C}-107$. The Graver filter flow rates for $0.05 \mathrm{wt} \%$ simulant (approximately $0.15 \mathrm{gpm} / \mathrm{f}^{2}$ ) were higher than those observed for 0.05 wt $\%$ C-107 sludge (approximately $0.1 \mathrm{gpm} / \mathrm{f}^{2}$ ), although the ionic strength was lower in the $\mathrm{C}-107$ samples. At high solids concentration (8 wt \%) the simulant exhibited lower flow rates (approximately $0.01 \mathrm{gpm} / \mathrm{f}^{2}$ ) than the $\mathrm{C}-107$ sludge (approximately 0.02 $\mathrm{gpm} / \mathrm{f}^{2}$ ). At low concentration this simulant exhibited higher fluxes than all of the actual wastes tested. At high concentrations, this simulant exhibited lower fluxes than actual wastes. The differences are likely attributed to the low ionic strength used in the actual waste tests with low solids concentration. 
WSRC-TR-97-00353

Page 27 of 28

\section{Acknowledgments}

This work was done as part of the DOE Office of Science and Technology, Tanks Focus Area program (TTP SR16-WT-41); C.P. McGinnis, Pretreatment Technical Integration Manager; D. Geiser, Office of Science and Technology Program Manager.

\section{References}

1. WSRC-TR-95-0337, "Evaluation and Ranking of the Tank Focus Area Solid Liquid Separation Needs (U)", D.J. McCabe, June 17, 1995.

2. WSRC-TR-96-0232, "Hanford and Oak Ridge Underground Storage Tank Waste Filtration Process Evaluation", R.A. Peterson, D.J. McCabe

3. WSRC-TR-95-0420, "Filter Performance Mechanisms", R.A. Peterson, C.A. Nash, October 1995.

4. J.G.H. Geeting and B.A. Reynolds, Bench-Scale "Crossflow Filtration of Hanford Tank C-106, C-107, B-110, and U-110 Sludge Slurries", PNNL-11652, UC-721, September, 1997. 
WSRC-TR-97-00353

Page 28 of 28

Authors

7. W. Walter

B.W. Walker

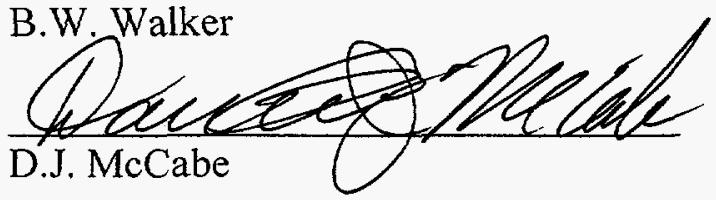

$12-9-97$

Date
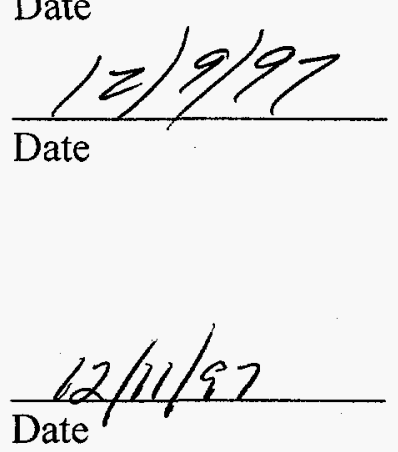

$12-10-97$

Date

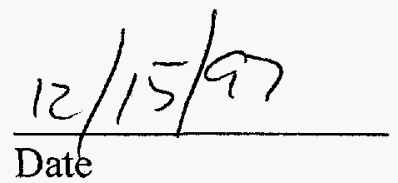

